\title{
MOLECULAR DYNAMICS SIMULATIONS OF PLASTIC DEFORMATION OF METALLIC SURFACES
}

\section{SIMULACIJE PLASTIČNE DEFORMACIJE KOVINSKIH POVRŠIN Z METODO MOLEKULARNE DINAMIKE}

\author{
Nuša Pukšičí, ${ }^{2}$, Monika Jenko ${ }^{1,2}$, Matjaž Godec ${ }^{1}$ \\ ${ }^{1}$ Institute of Metals and Technology, Lepi pot 11, Ljubljana, Slovenia \\ 2Jožef Stefan International Postgraduate School, Jamova cesta 39, Ljubljana, Slovenia \\ nusa.puksic@imt.si
}

Prejem rokopisa - received: 2016-12-12; sprejem za objavo - accepted for publication: 2016-12-23

doi: $10.17222 / \mathrm{mit} .2016 .334$

\begin{abstract}
An understanding of the physical properties of a wide array of geometries is important in the quest for ever smaller and more fine-tuned devices and their parts. Surfaces play a key role in the deformation of nano-scale systems. Molecular dynamics simulations of compressive and tensile deformation were performed on nickel and copper thin films with (111), (9 9 11) and (10 $108)$ surface orientations at $10 \mathrm{~K}$. The (9 911$)$ and (10 10 8) surfaces are vicinal to (111) and consist of a series of equidistant monoatomic steps. All the cases exhibit a yield stress asymmetry, with the yield stress being higher in compression than in tension. The near-surface region is the first to plastically deform and dislocations nucleate at the surface. The influence of the surface is most pronounced for the cases of the (10 10 8) surfaces deformed in compression, where parallel stacking faults nucleate at the steps on the surfaces in both materials, overriding the primary slip systems.

Keywords: molecular dynamics (MD), metallic surfaces, thin films, deformation
\end{abstract}

Dobro razumevanje mehanskih lastnosti široke palete geometrij je pomembno pri izboljšavah vedno manjših in zahtevnejših naprav in njihovih delov. Površine igrajo pomembno vlogo pri deformaciji sistemov na nano-skali. Z metodo molekularne

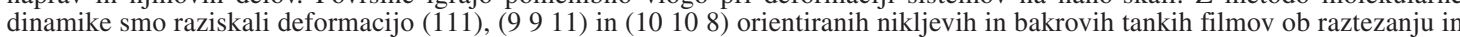
krčenju pri temperaturi $10 \mathrm{~K}$. Površini (9 9 11) in (10 10 8) sta sosednji nominalni površini (111) in sta sestavljeni iz ekvidistantnih stopnic. Vse površine imajo asimetrično mejo plastičnosti, ki je višja pri stiskanju kot pri raztezanju. Območja tik pod površino se najprej deformirajo in dislokacije izvirajo na površinah. Vpliv površine je najbolj izrazit za primera orientacije (10 10 8) pri stiskanju, ko se oba materiala deformirata s serijo vzporednih napak zloga, ki izvirajo iz stopnic na površinah in, ki nadomestijo primarne drsne sisteme.

Ključne besede: molekularna dinamika (MD), kovinske površine, tanki filmi, deformacija

\section{INTRODUCTION}

Experiments at the nanoscale can be very time consuming and costly, in addition, they often turn out ambiguous due to lack of constraint on the thin foils examined. Such experiments also require expensive equipment and sensors, which further motivates us to use atomistic simulations to better understand deformation mechanisms at the nanoscale. Molecular dynamics (MD) simulations can serve as an effective tool for analysing dislocation nucleation mechanisms in metallic materials. ${ }^{1-4}$

Whereas the misorientation of adjacent grains determines the precise positioning of the atoms close to the boundaries, leading to diverse defect nucleation sites, the surface condition similarly influences the mechanical response of a material to external loads or deformation due to the relaxation of the topmost layers minimizing the surface energy and the adjacent free space into which the atoms can move..$^{5-8}$

Vicinal surfaces, such as (10 10 8) and (9 9 11) investigated here, are produced by cutting a crystal close to a dense plane, and consist of terraces divided by equidistant monoatomic steps. When cutting or growing poly- crystalline materials, such surfaces are unavoidable. As is the case with grain boundaries, the steps on the surface provide favourable nucleation sites for dislocations and stacking faults, key elements of plastic deformation. We show that deformation mechanisms in copper and nickel are influenced by the presence of steps at the surface.

\section{EXPERIMENTAL PART}

The simulations were performed on an array of substrates, with surface orientations (111), (9 9 11) and (10 $108)$. The (9 911$)$ and (10 10 8) surfaces are vicinal to (111) and consist of a series of equidistant monoatomic steps that have (001) and (-1-11) oriented microfacets, respectively.

Copper and nickel single crystal thin films of $10 \mathrm{~nm}$ thickness were simulated. The simulations of the tensile and compressive uniaxial deformations were performed at $10 \mathrm{~K}$, applying engineering strain at a strain rate of $\pm 2.5 \% / \mathrm{ps}$. The strain direction was perpendicular to the steps.

The boundaries of the simulation boxes were periodic in the $\mathbf{x}$ and $\mathbf{y}$ directions and fixed in the $\mathbf{z}$ direction. 
In the $\mathbf{z}$ direction the simulated films were bound by a free surface at the top and by a layer of fixed atoms at the bottom to prevent the loss of atoms at the border of the simulation box and to simulate defect-free bulk. The thickness of this frozen layer was $1.2 \mathrm{~nm}$. These atoms were fixed at the positions they had when equilibrated to $10 \mathrm{~K}$ and were remapped at every deformation of the simulation box. All the forces acting on these atoms were otherwise reset to zero.

In the $\mathbf{y}$ direction the size of the simulation box was subject to requirements for periodicity of the terraces and steps for vicinal surfaces. The number of steps and terraces included was 8 .

To simulate engineering compressive and tensile strains, the simulation box was deformed in the $\mathbf{y}$ direction in increments of $0.5 \%$ with 200 fs periods of equilibration in-between, resulting in the overall strain rate of $2.5 \% / \mathrm{ps}$. The stress in the $\mathbf{x}$ direction was kept to zero.

The molecular dynamics simulations were carried out using the LAMMPS Molecular Dynamics Simulator ${ }^{9}$ and EAM potentials by Y. Mishin et al. ${ }^{10}$ OVITO $^{11}$ was used for visualization and analysis of the simulation data. Dislocation detection algorithm by A. Stukowski ${ }^{11}$ implemented in OVITO was used in post-processing.

\section{RESULTS}

Deformation mechanisms of copper and nickel (111), (9 $\left.9 \begin{array}{ll}9 & 11\end{array}\right)$ and (10 10 8) surfaces were investigated. Stress-strain curves are shown in Figures $\mathbf{1}$ and $\mathbf{2}$. As is expected from the direction of the strain, the Young modulus (expressed as the steepness of the stress-strain curve) is highest for the (9 9 11) surfaces and lowest for the (10 10 8) surfaces.

Yield stress is lower in copper than in nickel. Both materials exhibit the yield stress asymmetry, with yield stress being higher in compression than in tension. This is connected to the fact that the deformation mechanisms in compression and tension are not the same for any of the surfaces we investigated, although strict geometric analysis suggests otherwise: primary slip systems, namely $\{-111\}(0-11)$ and $\{1-11\}(-101)$, are the same for all the surfaces we investigated, with Schmidt factors of

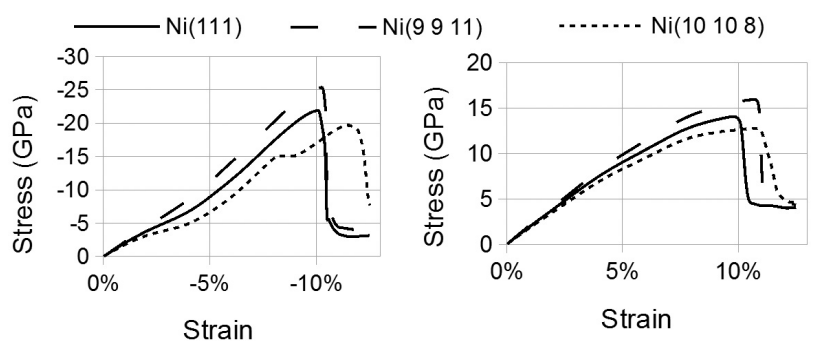

(a) Nickel, compressive deformation (b) Nickel, tensile deformation Figure 1: a) Stress-strain curves for nickel deformed in compression and $b$ ) in tension.

Slika 1: Diagrama napetost-raztezek za nikelj; a) pri kompresiji, b) pri napetosti.
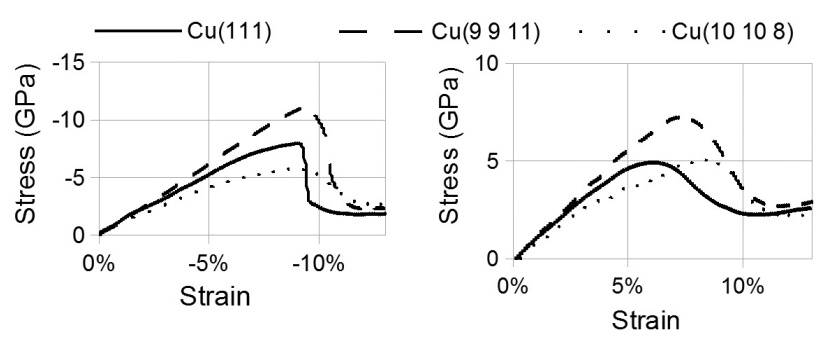

(a) Copper, compressive deformation (b) Copper, tensile deformation Figure 2: a) Stress-strain curves for copper deformed in a) compression and $b$ ) in tension.

Slika 2: Diagrama napetost-raztezek za baker: a) pri kompresiji, b) pri napetosti

0.408 for the (111) surface, 0.377 for (9 9 11) and 0.433 for (10 10 8).

In the case of $\mathrm{Cu}(111)$ surface deformed in tension, mostly stair-rod dislocations form throughout the bulk and are not limited to the near-surface region, while in compression, dislocations first nucleate at the surface as Schockley partials and no trailing partials detach from the surface.

In the case of $\mathrm{Ni}(111)$ surface deformed in tension, Schockeley partial dislocations nucleate in the bulk, while in compression, Schockley partials nucleate at the surface and trailing partials detach from the surface.

For all the (9 9 11) surfaces, Schockley partial dislocation nucleate at the surface and trailing partials detach from the surface. Stair-rod dislocations form in $\mathrm{Cu}(99$ 11) and $\mathrm{Ni}(99$ 11) deformed in tension, Figures $\mathbf{3 b}$ and 3f.

In the case of $\mathrm{Cu}\left(\begin{array}{lll}10 & 10 & 8\end{array}\right)$ surface deformed in tension, Figure 3a, stair-rod dislocations nucleate at the surface, while in compression, Figure 3c, parallel stacking faults nucleate at the steps and grow into the bulk.

In the case of $\mathrm{Ni}\left(\begin{array}{lll}10 & 10 & 8\end{array}\right)$ surface deformed in tension, Figure 3e, Schockley partial dislocation nucleate at the surface and in the near-surface region, while in compression, Figure 3g, parallel stacking faults nucleate at the steps and grow into the bulk.

\section{DISCUSSION}

We found two cases of easy glide where only one slip system is active: $\mathrm{Cu}\left(\begin{array}{lll}10 & 10 & 8\end{array}\right)$ and $\mathrm{Ni}\left(\begin{array}{lll}10 & 10 & 8\end{array}\right)$ surfaces deformed in compression, Figures 3c and 3g. Schockley partial dislocations nucleate at all the steps on the surface and grow evenly into the bulk. The stress-strain curves have a small plateau in the region just before the peak of the curve is expected, more pronounced in the case of nickel, and the peak is moved to higher strains, Figures 1a and 2a.

In the case of $\mathrm{Cu}\left(\begin{array}{ll}10 & 10\end{array}\right)$ deformed in tension, Figure 3a, Schockley partial dislocations wrapped around stair-rod dislocations form, also nucleating at the steps on the surface. As the stair-rod dislocations only move with diffusion, which is limited at this temperature, the 
N. PUKŠIČ et al.: MOLECULAR DYNAMICS SIMULATIONS OF PLASTIC DEFORMATION OF METALLIC SURFACES

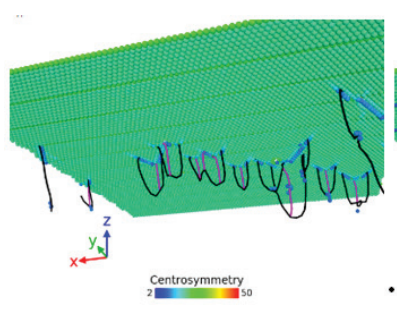

(a) $\mathrm{Cu}(10 \cdot 10 \cdot 8)$, tensile

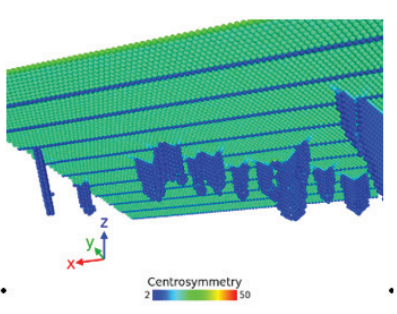

Centrosymmetry
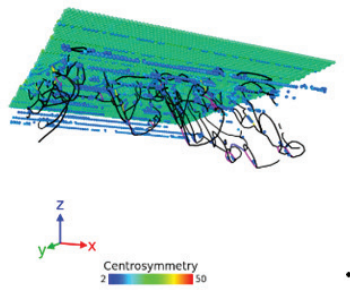

(b) $\cdot \mathrm{Cu}(9 \cdot 9 \cdot 11)$, tensile
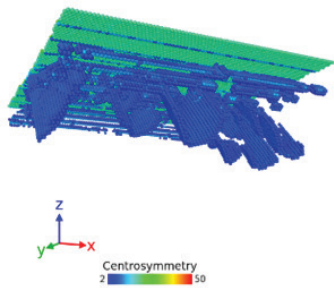

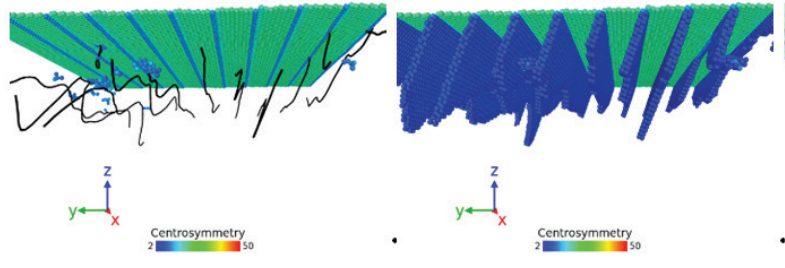

(c) $\cdot \mathrm{Cu}(10 \cdot 10 \cdot 8)$, compressive

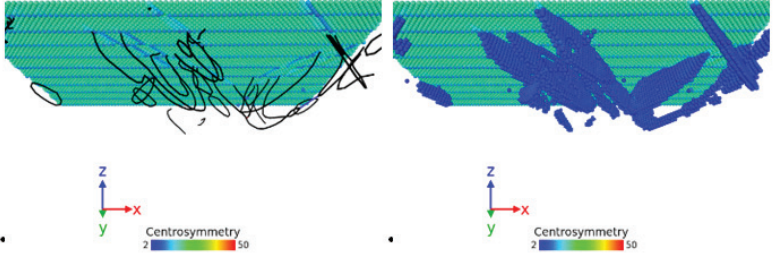

(d) $\mathrm{Cu}(9 \cdot 9 \cdot 11)$, compressive

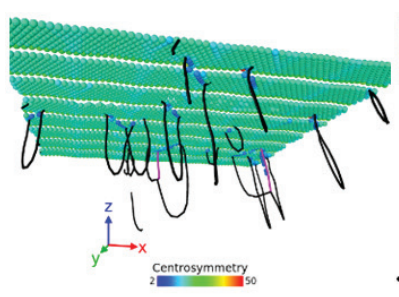

(e) $\cdot \mathrm{Ni}(10 \cdot 10 \cdot 8)$, tensile

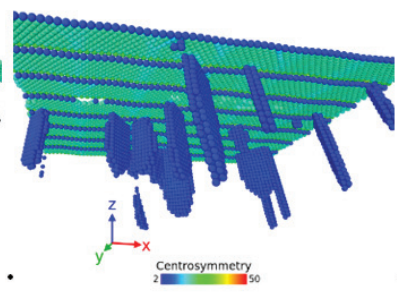

$x$ centrosymmetry
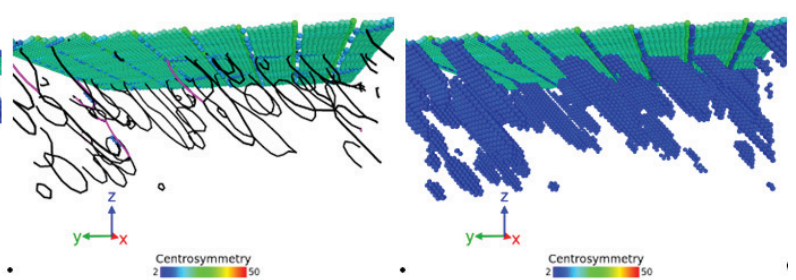

(f) $\cdot \operatorname{Ni}(9 \cdot 9 \cdot 11)$, tensile

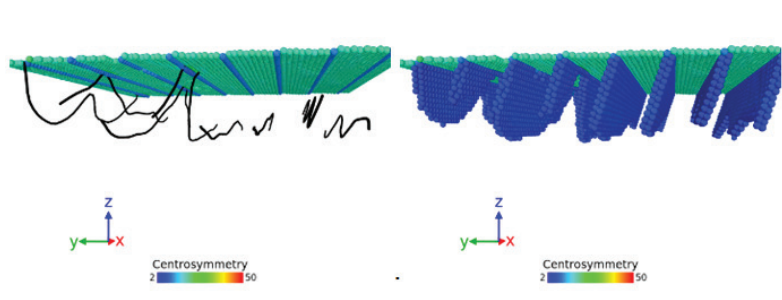

(g) $\cdot \mathrm{Ni}(10 \cdot 10 \cdot 8)$, compressive
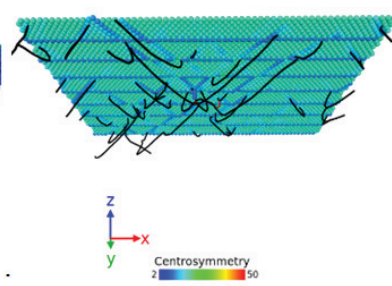

(h) $\cdot \mathrm{Ni}(9 \cdot 9 \cdot 11)$, compressive

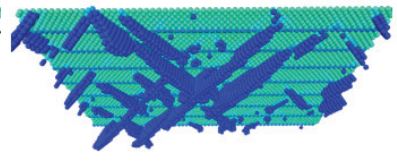

Figure 3: Dislocation nucleation in copper and nickel thin films deformed in tension and in compression. Two views are shown for each case: dislocations as lines (left) and atoms with centrosymmetry parameter CS > 2 (right). Black lines denote Schockley partial dislocations and pink lines denote stair-rod dislocations.

Slika 3: Začetki plastične deformacije $\mathrm{v}$ bakrovih in nikljevih stiskanih in raztezanih tankih filmih. Vsak primer prikazujeta dva pogleda: dislokacije označene s črtami (levo) in atomi s parametrom središčne simetrije CS > 2 (desno). Črne črte označujejo Schocklyeve delne dislokacije, roza črte pa Lomer-Cottrell stike.

effect on stress is the same as if only one slip system were active and the stress-strain curve exhibits a change in slope, Figure $2 \mathbf{b}$.

A. Zimmerman et al. ${ }^{12}$ studied Au(111) surfaces with single monoatomic steps at $0 \mathrm{~K}$ and found that when the indenter came into physical contact with the step, the deformation mechanism beneath the indenter switched from dislocation emission from the surface to slip aligned with the step.

D. Shan et al. ${ }^{13}$ performed a similar study of nanoindentation on thin copper films and found that when the indenter came into contact with the step, there was a significant difference in the strength of the first dislocation emission.

H. Lu and $\mathrm{Y} . \mathrm{Ni}^{14}$ and $\mathrm{H}$. Lu et al. ${ }^{15}$ investigated the effects of surface steps on nanoindentation in $\mathrm{Al}$ and found that the shear stress resulting from the step influences the choice of the active slip systems and lowers the threshold for plastic deformation.

Our analysis shows that it is not only the presence of steps that influences deformation mechanisms. While a switch to slip aligned with the steps occurs for the (10 10 


\section{MATERIALI IN TEHNOLOGIJE/MATERIALS AND TECHNOLOGY (1967-2017) - 50 LET/50 YEARS}

\section{N. PUKŠIČ et al.: MOLECULAR DYNAMICS SIMULATIONS OF PLASTIC DEFORMATION OF METALLIC SURFACES}

8) surfaces deformed in compression for both materials we investigated, we found no such switch for the (9 9 11) surfaces.

The near-surface region is the first to plastically deform and dislocations nucleate at the surface, therefore the surfaces are softer than the bulk. We conclude that the stress inherent in the steps also lowered the threshold for plastic deformation in our systems.

\section{CONCLUSIONS}

Deformation mechanisms of copper and nickel thin films we investigated are more complex than geometric analysis would suggest. The surfaces are softer than the bulk, as the near-surface region is the first to plastically deform and dislocations nucleate at the surface. We conclude that the stress inherent in the steps lowered the threshold for plastic deformation in the thin films we investigated.

In tensile deformation in both materials, stair-rod dislocations nucleate at the surfaces and are not created by dislocation interactions.

The influence of the surface is most pronounced for the cases of the (10 10 8) surfaces deformed in compression, where parallel stacking faults nucleate at the steps on the surfaces in both materials, overriding the primary slip systems. The presence of the steps does not in itself influence the choice of slip systems. While a switch to slip aligned with the steps occurs for the (10 10 8) surfaces deformed in compression for both materials we investigated, we found no such switch for the (9 9 11) surfaces.

\section{Acknowledgement}

The authors acknowledge the financial support of the Slovenian Research Agency (ARRS).

\section{REFERENCES}

${ }^{1}$ P. Muller, Elastic effects on surface physics, Surface Science Reports, 54 (2004) 157-258, doi:10.1016/j.surfrep.2004.05.001
${ }^{2}$ Z. You, X. Li, L. Gui, Q. Lu, T. Zhu, H. Gao, L. Lu, Plastic anisotropy and associated deformation mechanisms in nanotwinned metals, Acta Materialia, 61 (2013) 217-227, doi:10.1016/j.actamat. 2012.09.052

${ }^{3}$ D. Huang, Q. Zhang, P. Qiao, Molecular dynamics evaluation of strain rate and size effects on mechanical properties of FCC nickel nanowires, Computational Materials Science, 50 (2011) 903-910, doi:10.1016/j.commatsci.2010.10.028

${ }^{4}$ F. Ma, K.-W. Xu, P. K. Chu, Surface-induced structural transformation in nanowires, Materials Science and Engineering: R: Reports, 74 (2013) 173-209, doi:10.1016/j.mser.2013.05.001

${ }^{5}$ D. Spearot, L. Capolungo, J. Qu, M. Cherkaoui, On the elastic tensile deformation of $\mathrm{d}$ bicrystal interfaces in copper, Computational Materials Science, 42 (2008) 57-67, doi:10.1016/j.commatsci.2007. 06.008

${ }^{6}$ M. Chassagne, M. Legros, D. Rodney, Atomic-scale simulation of screw dislocation/coherent twin boundary interaction in $\mathrm{Al}, \mathrm{Au}, \mathrm{Cu}$ and Ni, Acta Materialia, 59 (2011) 1456-1463, doi:10.1016/ j.actamat.2010.11.007

${ }^{7}$ D. Bachurin, D. Weygand, P. Gumbsch, Dislocation-grain boundary interaction in o textured thin metal films, Acta Materialia, 58 (2010) 5232-5241, doi:10.1016/j.actamat.2010.06.026

${ }^{8}$ H. S. Park, K. Gall, J. A. Zimmerman, Deformation of FCC nanowires by twinning and slip, Journal of the Mechanics and Physics of Solids, 54 (2006) 1862-1881, doi:10.1016/j.jmps.2006.03.006

${ }^{9}$ S. Plimpton, Fast Parallel Algorithms for Short-Range Molecular Dynamics, Journal of Computational Physics, (1995) 1-19, doi:10.1006/jcph.1995.1039, URL http://lammps.sandia.gov/

${ }^{10}$ Y. Mishin, M. Mehl, D. Papaconstantopoulos, A. Voter, J. Kress, Structural stability and lattice defects in copper: Ab initio, tight-binding, and embedded-atom calculations, Physical Review B, 63 (2001) 224106, doi:10.1103/PhysRevB.63.224106

${ }^{11}$ A. Stukowski, Visualization and analysis of atomistic simulation data with OVITO-the Open Visualization Tool, Modelling and Simulation in Materials Science and Engineering, 18 (2010) 015012, doi:10.1088/0965-0393/18/1/015012

${ }^{12}$ J.A. Zimmerman, C. L. Kelchner, P. A. Klein, J. C. Hamilton, S. M. Foiles, Surface step effects on nanoindentation, Phys. Rev. Lett., 87 (2001) 165507, doi:10.1103/PhysRevLett.87.165507

${ }^{13}$ D. Shan, L. Yuan, B. Guo, Multiscale simulation of surface step effects on nanoindentation, Materials Science and Engineering: A, 412 (2005) 264-270, doi:10.1016/j.msea.2005.08.198

${ }^{14} \mathrm{H}$. Lu, Y. Ni, Effect of surface step on nanoindentation of thin films by multiscale analysis, Thin Solid Films, 520 (2012) 4934-4940, doi:10.1016/j.tsf.2012.03.019

${ }^{15}$ H. Lu, Y. Ni, J. Mei, J. Li, H. Wang, Anisotropic plastic deformation beneath surface step during nanoindentation of FCC Al by multiscale analysis, Computational Materials Science, 58 (2012), 192-200, doi:10.1016/j.commatsci.2012.01.026 